University of Nebraska - Lincoln

DigitalCommons@University of Nebraska - Lincoln

Related Publications from ANDRILL Affiliates

Antarctic Drilling Program

2007

\title{
100 Million Years of Antarctic Climate Evolution: Evidence from Fossil Plants
}

J. E. Francis

University of Leeds, j.francis@earth.leeds.ac.uk

A. Ashworth

North Dakota State University

D. J. Cantrill

National Herbarium of Victoria

J. A. Crame

British Antarctic Survey

J. Howe

University of Leeds

See next page for additional authors

Follow this and additional works at: https://digitalcommons.unl.edu/andrillaffiliates

Part of the Environmental Indicators and Impact Assessment Commons

Francis, J. E.; Ashworth, A.; Cantrill, D. J.; Crame, J. A.; Howe, J.; Stephens, R.; Tosolini, A.-M.; and Thorn, V., "100 Million Years of Antarctic Climate Evolution: Evidence from Fossil Plants" (2007). Related Publications from ANDRILL Affiliates. 3.

https://digitalcommons.unl.edu/andrillaffiliates/3

This Article is brought to you for free and open access by the Antarctic Drilling Program at DigitalCommons@University of Nebraska - Lincoln. It has been accepted for inclusion in Related Publications from ANDRILL Affiliates by an authorized administrator of DigitalCommons@University of Nebraska - Lincoln. 


\section{Authors}

J. E. Francis, A. Ashworth, D. J. Cantrill, J. A. Crame, J. Howe, R. Stephens, A.-M. Tosolini, and V. Thorn 


\title{
100 Million Years of Antarctic Climate Evolution: Evidence from Fossil Plants
}

\author{
J. E. Francis, ${ }^{l}$ A. Ashworth, ${ }^{2}$ D. J. Cantrill, ${ }^{3}$ J. A. Crame, ${ }^{4}$ J. Howe, ${ }^{1}$ R. Stephens, ${ }^{l}$ A.-M. Tosolini, ${ }^{1}$ V. Thorn ${ }^{l}$
}

\begin{abstract}
The evolution of Antarctic climate from a Cretaceous greenhouse into the Neogene icehouse is captured within a rich record of fossil leaves, wood, pollen, and flowers from the Antarctic Peninsula and the Transantarctic Mountains. About 85 million years ago, during the mid-Late Cretaceous, flowering plants thrived in subtropical climates in Antarctica. Analysis of their leaves and flowers, many of which were ancestors of plants that live in the tropics today, indicates that summer temperatures averaged $20^{\circ} \mathrm{C}$ during this global thermal maximum. After the Paleocene ( $60 \mathrm{Ma})$ warmthloving plants gradually lost their place in the vegetation and were replaced by floras dominated by araucarian conifers (monkey puzzles) and the southern beech Nothofagus, which tolerated freezing winters. Plants hung on tenaciously in high latitudes, even after ice sheets covered the land, and during periods of interglacial warmth in the Neogene small dwarf plants survived in tundra-like conditions within $500 \mathrm{~km}$ of the South Pole.
\end{abstract}

\section{INTRODUCTION}

The Antarctic Paradox is that, despite the continent being the most inhospitable continent on Earth with its freezing

\footnotetext{
${ }^{1}$ School of Earth and Environment, University of Leeds, UK.

${ }^{2}$ Department of Geosciences, North Dakota State University, Fargo, ND 58105-5517, USA.

${ }^{3}$ National Herbarium of Victoria, Royal Botanic Gardens Melbourne, Private Bag 2000, South Yarra, Victoria 3141, Australia.

${ }^{4}$ British Antarctic Survey, High Cross, Madingley Road, Cambridge, UK.
}

climate and 4-km-thick ice cap, some of the most common fossils preserved in its rock record are those of ancient plants. These fossils testify to a different world of globally warm and ice-free climates, where dense vegetation was able to survive very close to the poles. The fossil plants are an important source of information about terrestrial climates in high latitudes, the regions on Earth most sensitive to climate change.

Although plants of Permian and Triassic age provide a signal of terrestrial climates for the Transantarctic region for times beyond 100 million years (Taylor and Taylor, 1990), it is during the Cretaceous that the Antarctic continent reached the approximate position that it is in today over the South Pole (Lawver et al., 1992). Without the cover of ice Cretaceous vegetation flourished at high latitudes. Even when ice built up on the continent during the Cenozoic, fossil plants indicate that vegetation was still able to grow in relatively inhospitable conditions. The plant record thus provides us with a window into past climates of Antarctica, particularly during the critical transition from greenhouse to icehouse (Francis et al., forthcoming).

Reviews of the paleobotany that focus on floral evolution, rather than paleoclimate, can be found in the work of Askin (1992) and Cantrill and Poole (2002, 2005) and references therein. This paper is not intended to be an exhaustive review of all paleoclimate or paleobotanical studies but presents new information about Antarctic climate evolution deduced from some new and some selected published studies of fossil plants.

\section{WARMTH IN THE CRETACEOUS GREENHOUSE}

The most detailed record of Cretaceous terrestrial climates from plants comes from Alexander Island on the Antarctic 


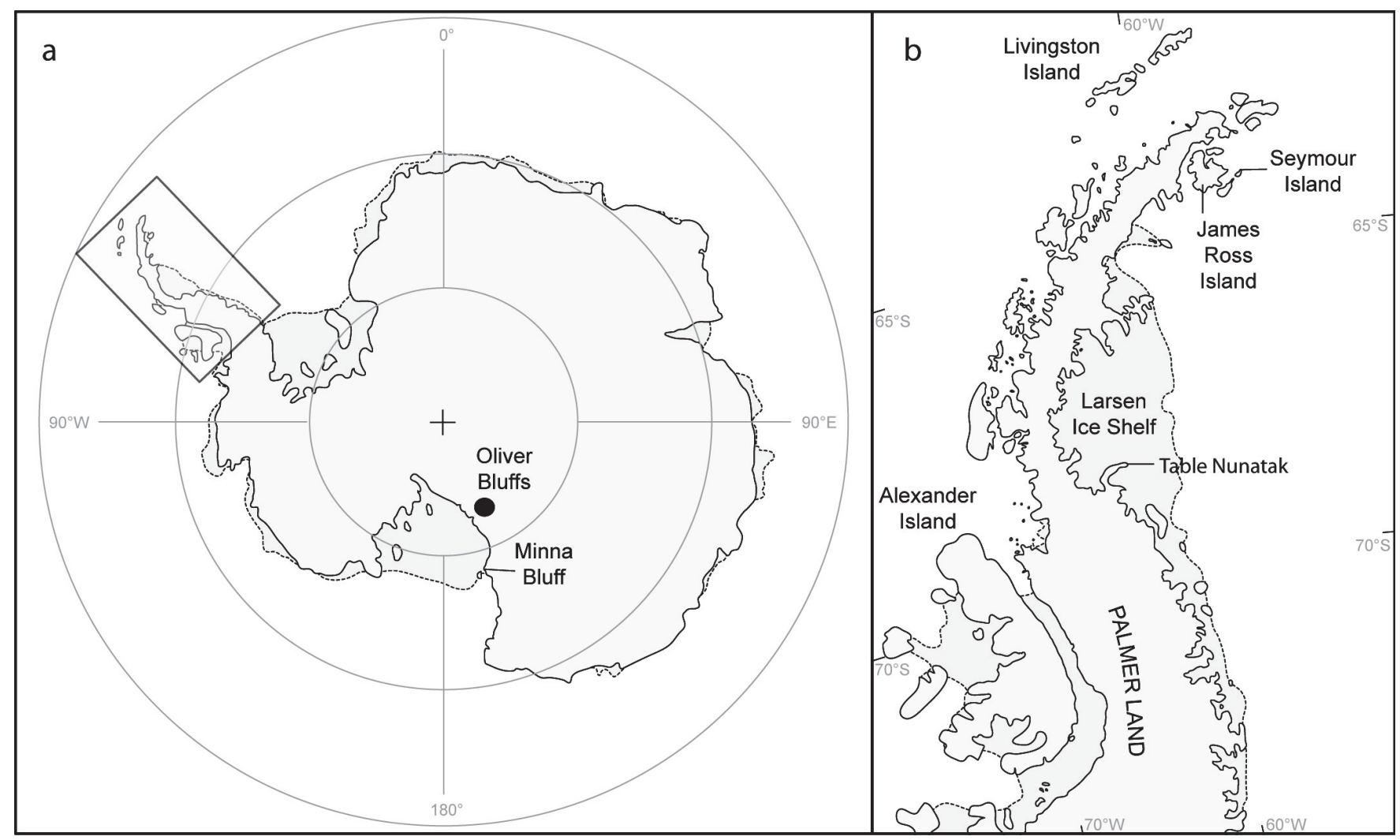

FIGURE 1 Map of Antarctica showing locations mentioned in the text.

Peninsula (Figure 1). Here the mid-Cretaceous (Albian) Fossil Bluff Group sediments include a series of marine, submarine fan, fluviatile, and deltaic sediments formed as the infill of a subsiding fore-arc basin. Floodplains and midchannel bars of braided and meandering river systems (Triton Point Formation, Nichols and Cantrill, 2002) were extensively forested by large trees with a rich undergrowth.

Many of the plants are preserved in their original positions, having been encased by sheet flood and crevasse splay deposits during catastrophic flooding events. In addition, finely laminated flood deposits draped small plants, preserving them in place.

The in situ preservation of the plants has allowed detailed reconstructions of the forest environments by Howe (2003). Three vegetation assemblages were identified through statistical analysis of field data: (1) a conifer and fern assemblage with mature conifers of mainly araucarian type and an understory of Sphenopteris ferns; (2) a mixed conifer, fern, and cycad assemblage with araucarian conifers and ginkgo trees; and (3) a disturbance flora of liverworts, Taeniopteris shrubs, ferns, and angiosperms. Reconstructions of these assemblages and their depositional setting are presented in Figure 2.

An artist's reconstruction is presented in Figure 3. This reconstruction portrays spacing of the large trees, such as ginkgos, podocarps, and araucarian conifers, as accurately as possible from field data. The undergrowth consists of ferns, cycadophytes, liverworts, mosses, and small shrubby angiosperms. The extinct plant Taeniopteris formed thickets in the disturbed clearings in the forest (Cantrill and Howe, 2001). The picture also shows the volcanoes on the adjacent arc that were the source of volcaniclastic sediment, much of which was deposited as catastrophic deposits that engulfed standing trees (in the distance in this picture).

Paleoclimatic interpretation using fossil plants on Alexander Island is based mainly on comparison with the ecological tolerances of similar living Southern Hemisphere taxa (Falcon-Lang et al., 2001). This indicates that the climate was generally warm and humid to allow the growth of large conifers, with mosses and ferns in the undergrowth. According to Nichols and Cantrill (2002), river flow is considered to have been perennial, based on sedimentary evidence, but with periodic floods indicative of high rainfall.

Evidence from fossil soils, however, provides a somewhat different climate story. The paleosols, in which trees are rooted, have structures such as blocky peds, clay cutans, and mottling that are typical of modern soils that form under seasonally dry climates (Howe and Francis, 2005). Although 

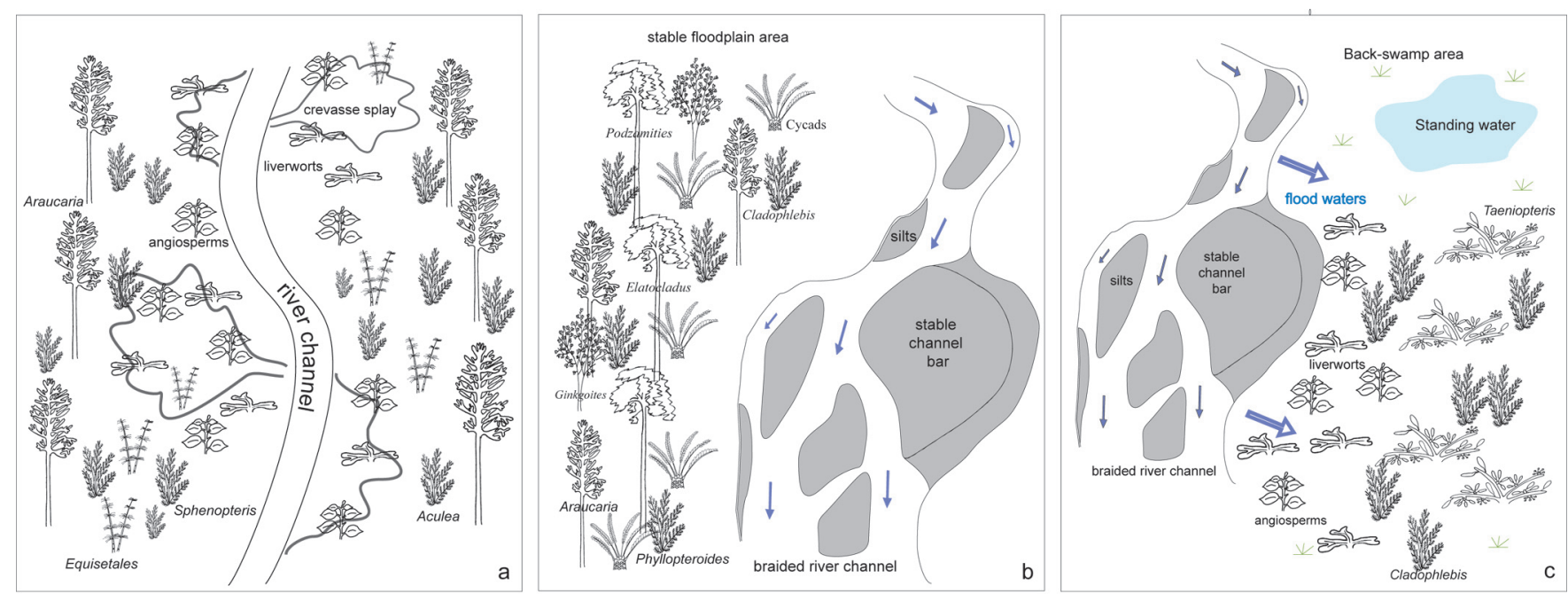

FIGURE 2 Reconstruction of paleoenvironment and community structure of (a) an open woodland community that grew on areas of the floodplain distal to a meandering river channel but subjected to frequent, low-energy floods; (b) a patch forest community of mature conifers and ferns, growing on floodplain areas affected by catastrophic floods; and (c) disturbance vegetation growing in back-swamp areas of a braided river floodplain, subjected to frequent low-energy flood events and ponding (Howe, 2003).

evidence of intermittent flooding is apparent from the fluvial sandstones and mudstones that volumetrically dominate the rock sequence, the paleosols indicate that this high-latitude mid-Cretaceous environment was predominantly seasonally dry. Whereas the flood sediments are likely to have been deposited relatively rapidly (days or weeks), the paleosols likely represent hundreds to thousands of years for soil development and forest growth, suggesting a predominantly dry climate for this high-latitude site.

Climate models for the mid-Cretaceous predicted warm, humid climates for this region. Valdes et al. (1996) predicted high summer temperatures of $20-24^{\circ} \mathrm{C}$ and low winter temperatures just above freezing. There is no evidence of freezing in the paleosols. However, it is likely that the more significant climate parameter that influenced the soils was rainfall and soil moisture. The models of Valdes et al. (1996) of seasonal mean surface soil moisture distribution (the balance between precipitation and evaporation) predict a seasonal moisture regime with dry conditions in summer but wet in winter, supporting the seasonal signature seen in the paleosols.

Younger Cretaceous strata preserved within the James Ross Island back-arc basin, and which crop out on James Ross, Seymour, and adjacent islands, contain a series of fossil floras that are providing new information about biodiversity and climate. During the Late Cretaceous angiosperms (flowering plants) became an important component of the vegetation. The Coniacian Hidden Lake Formation (Gustav Group) and the Santonian-early Campanian Santa Marta Formation (Marambio Group) in particular contain fossil angiosperm leaves that have yielded information about paleoclimate. The leaves represent the remains of vegetation that grew at approximately $65^{\circ} \mathrm{S}$ on the emergent volcanic arc that is now represented by the Antarctic Peninsula. They were subsequently transported and buried in marine sediments in the adjacent back-arc basin, and are now preserved as impressions and compressions in volcaniclastic siltstones and carbonate concretions (Hayes et al., 2006).

The angiosperm leaf morphotypes have been tentatively compared with those of living families such as Sterculiaceae, Lauraceae, Winteraceae, Cunoniaceae, and Myrtaceae (Hayes et al., 2006) (Figure 4). Most of these families today can be found in warm temperate or subtropical zones of the Southern Hemisphere. Sterculiaceae is a tropical and subtropical family found in Australia, South Asia, Africa, and northern South and Central America. The Laurales today live in tropical or warm temperate regions with a moist equable climate. Both the Cunoniaceae and Elaeocarpaceae are tropical and subtropical trees and shrubs found in equatorial tropical regions, and the Winteraceae are concentrated in wet tropical montane to cool temperate rainforests of the southwest Pacific and South America.

A more quantitative analysis of the leaves based on physiognomic aspects of the leaves, using leaf margin analysis and simple and multiple linear regression models, provided data on paleotemperatures and precipitation. Estimates of mean annual temperatures (MATs) range from $15.2( \pm 2)$ to $18.6( \pm 1.9)^{\circ} \mathrm{C}$ for the Coniacian, and $17.1( \pm 2)^{\circ} \mathrm{C}$ to 21.2 $( \pm 1.9)^{\circ} \mathrm{C}$ for the late Coniacian-early Santonian. Averaging all data from all methods gives a MAT for the Coniacian of $16.9^{\circ} \mathrm{C}$ and $19.1^{\circ} \mathrm{C}$ for the late Coniacian-early Santonian (Hayes et al., 2006). Estimates of annual precipitation range 


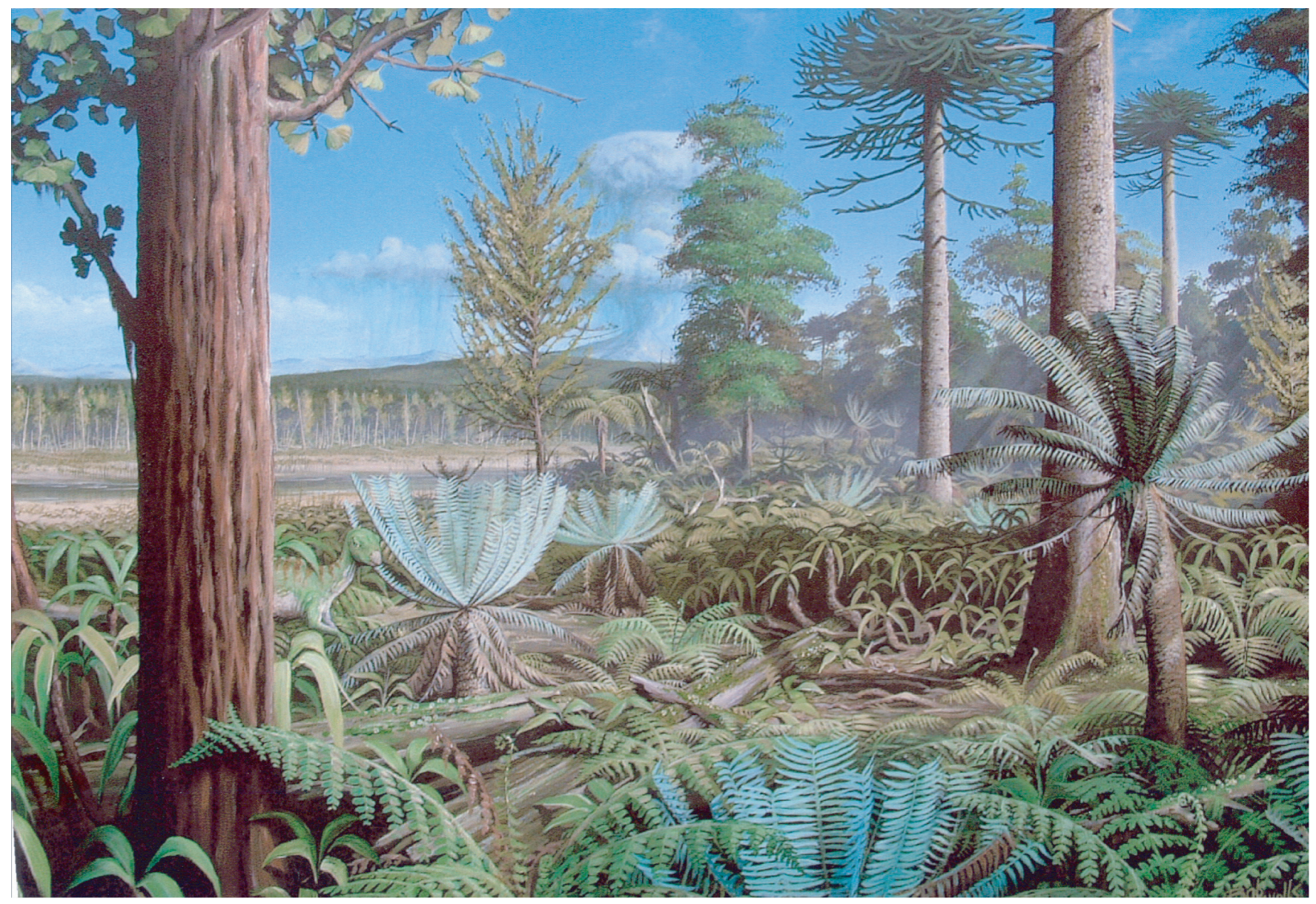

FIGURE 3 Reconstruction of the forest environment on Alexander Island during the Cretaceous, based on the work of Howe (2003) and British Antarctic Survey geologists (see text and references).

SOURCE: Image is a painting by Robert Nicholls of Paleocreations.com, and is housed at the British Antarctic Survey.

from 594 to $2142( \pm 580) \mathrm{mm}$ for the Coniacian and 673 to $1991( \pm 580) \mathrm{mm}$, for the late Coniacian-early Santonian, with very high rainfalls of $2630( \pm 482)$ and $2450( \pm 482) \mathrm{mm}$ for the growing seasons, respectively, comparable with those of equatorial tropical rainforests today. However, these data must be considered with caution as some important aspects of leaf morphology related to rainfall are not preserved in the fossil assemblage.

These fossil plants are thus indicative of tropical and subtropical climates at high paleolatitudes during the midLate Cretaceous, without extended periods of winter temperatures below freezing and with adequate moisture for growth. In other Antarctic paleoclimate studies evidence for strong warmth at this time was found by Dingle and Lavelle (1998) in their analyses of clay minerals and from analysis of fossil woods (Poole et al., 2005). This warm peak may have also been the trigger for the expansion of the angiosperms in the Antarctic, represented by a marked increased abundance of angiosperm pollen in Turonian sediments (Keating et al., 1992). On a global scale this corresponds to the Cretaceous thermal maximum, from about 100-80 Ma, reported from many sites (e.g., Clark and Jenkyns, 1999; Huber et al., 2002), and possibly attributed to rising atmospheric $\mathrm{CO}_{2}$ levels due to a tectonically driven oceanographic event in the opening of the equatorial Atlantic gateway (Poulsen et al., 2003).

The high levels of Cretaceous climate warmth are also recorded in an unusual assemblage of late Santonian fossil plants from Table Nunatak on the east side of the Antarctic Peninsula. A small isolated outcrop has yielded layers of charcoal, produced by wildfires, within a sequence of sandstones, siltstones, and mudstones, deposited in shallow marine conditions at the mouth of an estuary or in a delta distributary channel. The charcoal layer contains the remains of burnt plants, including megaspores; fern rachids; conifer leaves, wood, shoots, seeds and pollen cones; angiosperms leaves, fruits and seeds (Eklund et al., 2004).

The most unusual of these fossils are tiny fossil flowers, the oldest recorded from Antarctica. Eklund (2003) identified several types of angiosperm flowers, some of which are most likely related to the living families Siparunaceae, Wintera- 

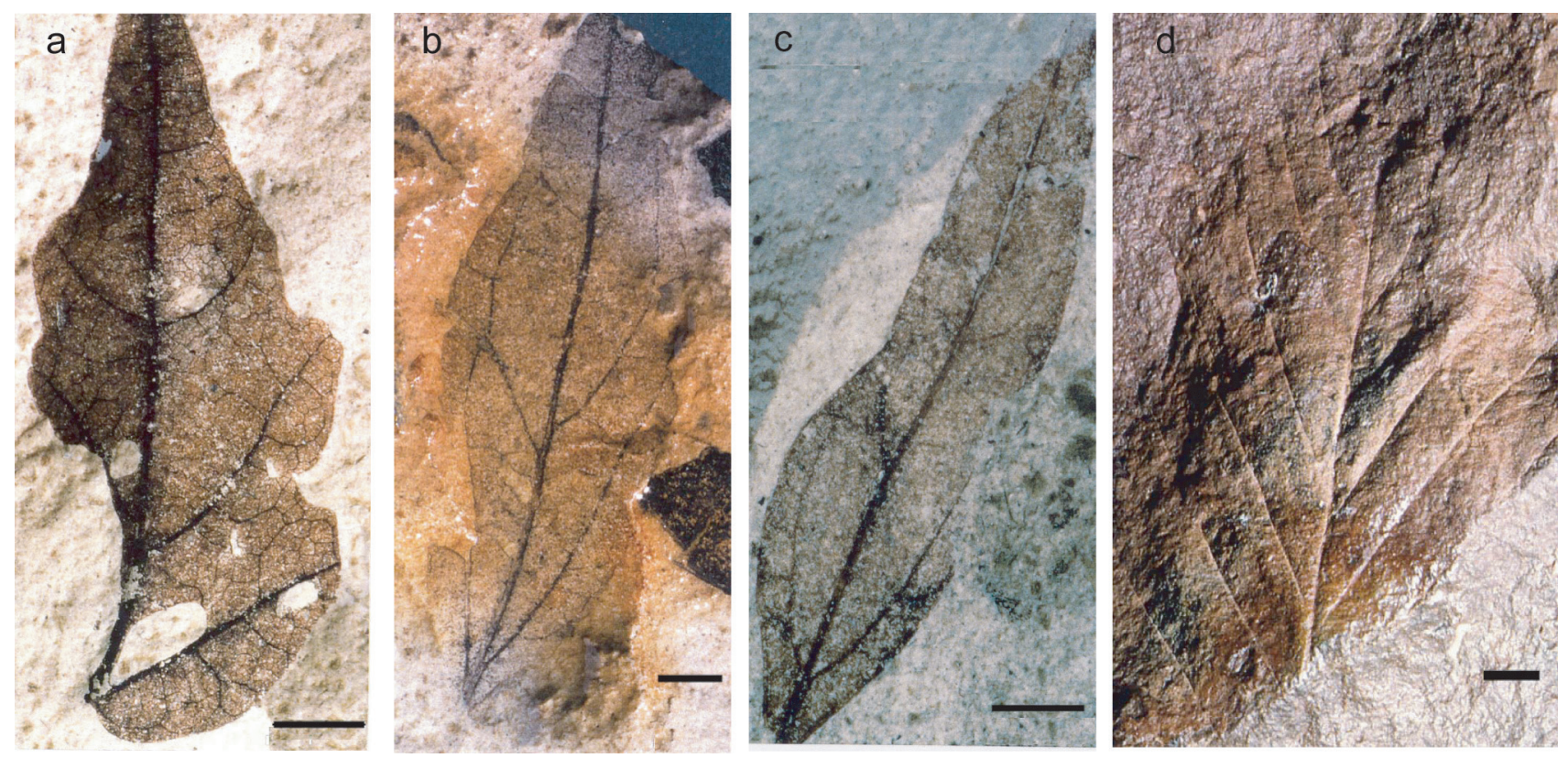

FIGURE 4 A selection of fossil leaves from the Hidden Lake Formation: (a) D.8754.1a, Morphotype 2 (Sterculiaceae); (b) D.8754.8.54a, Morphotype 11 (Laurales); (c) D.8754.8.57a, Morphotype 11 (Laurales); (d) D.8621.27a, Morphotype 10 (unknown affinity). Botanical names in parentheses refer to most similar modern family (Hayes et al., 2006). Scale bar $5 \mathrm{~mm}$ for all leaves. Numbers refer to the British Antarctic Survey numbering system.

ceae, and Myrtaceae, as well as several unidentified types. The Siparunaceae family is now confined to the tropics, and the Winteraceae (e.g., mountain pepper tree) and Myrtaceae (e.g., eucalypts) are warm-cool temperate types from the Southern Hemisphere. Interestingly, the Siparuna-like fossil flowers have a flat-roofed structure with a central pore, which in the living plants acts as a landing platform for gall midges that lay their eggs inside the flower head. Since the developing gall midge larvae usually destroy the flowers as they grow (Eklund, 2003), the preservation of such flowers as fossils would normally be extremely unlikely. The fortuitous occurrence of wildfires during the Cretaceous has thus helped preserve such flowers as rare fossils.

\section{FROM GREENHOUSE TO ICEHOUSE}

After the peak warmth of the mid-Late Cretaceous, climate appears to have cooled globally during the latest part of the Cretaceous, as seen also in the Antarctic fossil wood record (Francis and Poole, 2002; Poole et al., 2005). However, warm climates returned to the high latitudes during the Paleocene and early Eocene, as is reflected in fossil plants.

The Paleogene sedimentary sequence on Seymour Island (Figure 1) contains plant-rich horizons that hold signals to ancient climates. An unusual new flora from La Meseta Formation has been studied by Stephens (2008). The flora is dominated by permineralized branches of conifers and compressions of angiosperm leaves, and found within car- bonate concretions within the shallow marine Campamento allomember of Marenssi et al. (1998) (equivalent to Telm 3 of Sadler [1988]). This unit has been dated as 51.5-49.5 Ma through links with global eustatic lowstands (Marenssi, 2006) and by Sr dating by Stephens, which yielded a latest early Eocene (late Ypresian) age.

The flora is unusual in that it is dominated by leaves, cone scales, and leafy branches of araucarian conifers, very similar in all respects to living Araucaria araucana (monkey puzzle) from Chile. Study of three-dimensional arrangement of leaves using the technique of neutron tomography illustrates that leaf and branch arrangement is characteristic of living Araucaria araucana (Figure 5). A limited array of angiosperm leaves are preserved in the nodules and include morphotypes that are similar to leaves of living Lauraceae, Myricaceae, Myrtaceae, and Proteaceae. It is notable that many of the fossil leaves appear to have particularly thick carbonaceous compressions and, indeed, the living equivalents are evergreen Southern Hemisphere trees that have thick waxy cuticles. This may signal taphonomic sorting of some kind rather than a climate signal, as the more fragile leaves, including Nothofagus, are unusually absent from this flora. Climate interpretation of this flora, based on the nearest living types, especially the araucarian conifers, suggests that the latest Eocene climate was cool and moist. Oxygen isotope analyses of marine molluscs in the same concretions yielded cool marine paleotemperatures of $8.3-12.5^{\circ} \mathrm{C}$, comparable to other estimates for Telm 3 from marine oxygen isotopes 

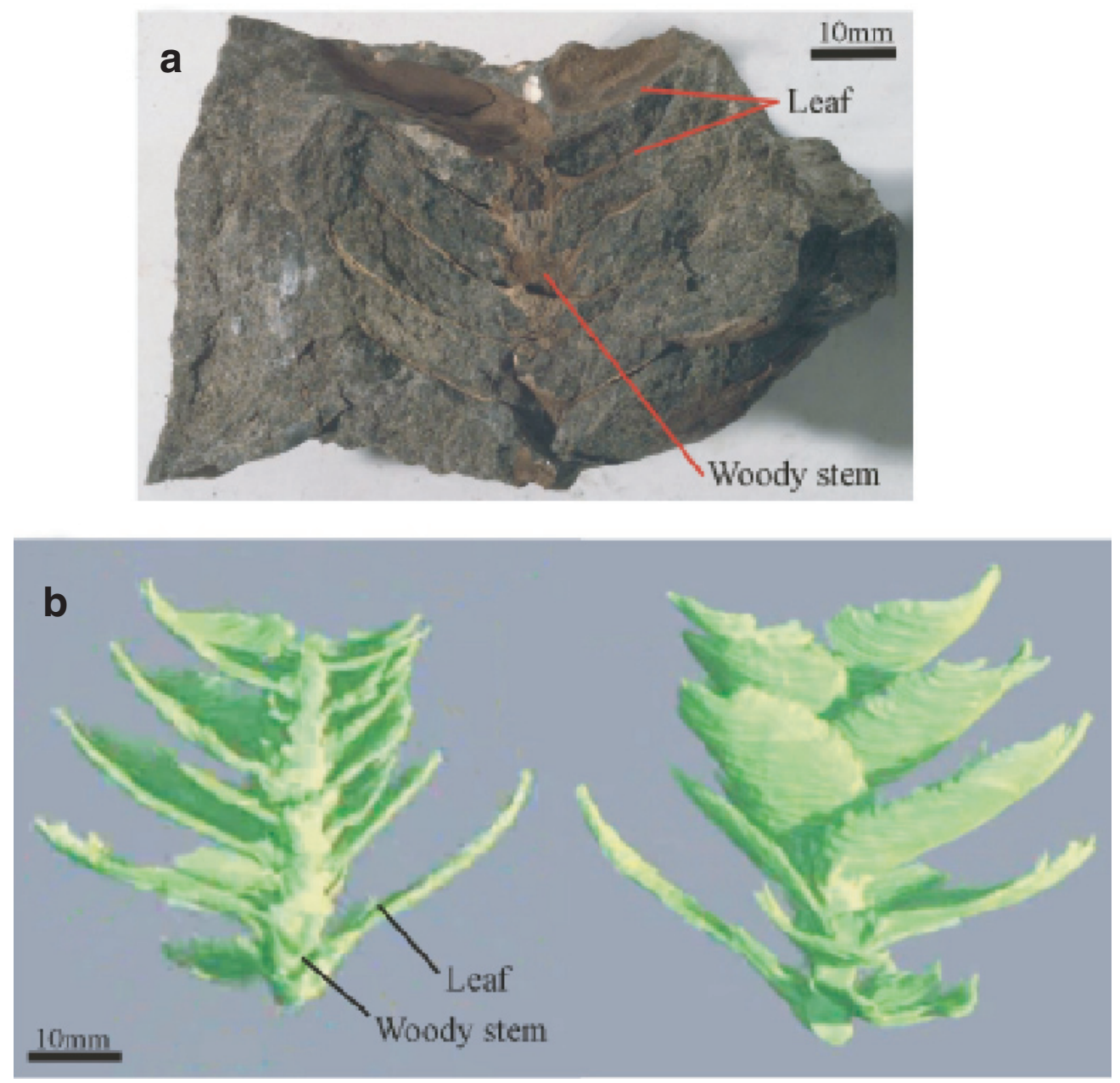

FIGURE 5 Image of three-dimensional leafy branch of fossil araucarian conifer from La Meseta Formation, Seymour Island (sample DJ.1103.189). (a) The branch as it appears in hand specimen. (b) Reconstruction from tomographic image showing the leafy branch in three dimensions. Neutron tomography to create the figure was undertaken at the Institut Laue Langevin facility, Grenoble, France.

of $8-13.2^{\circ} \mathrm{C}$ (Pirrie et al., 1998) and $10.5-19.6^{\circ} \mathrm{C}$ (Dutton et al., 2002).

New paleoclimate data have also been derived from new collections of fossil angiosperm leaves from the Nordenskjold flora in the Cross Valley Formation of Late Paleocene age (Elliot and Trautman, 1982) and from the Middle Eocene Cucullaea 1 flora (Telm 5 of Sadler [1988], Cucullaea 1 allomember of Marenssi et al. [1998], dated as 47-44 Ma by Dutton et al. [2002]). In the Late Paleocene flora 36 angiosperm leaf morphotypes were identified, along with two pteridophytes (ferns), and podocarp and araucarian conifers. The angiosperm leaf component is dominated by types with possibly modern affinities to the Nothofagacae, Lauraceae, and Proteaceae, along with other types, such as Myrtaceae, Elaeocarpaceae, Winteraceae, Moraceae, Cunoniaceae, and Monimiaceae, some of which have no identifiable modern affinities as yet. The fossil assemblage contains a mix of families of subtropical and cool-temperate nature and represents cool-warm temperate mixed conifer-broad-leaved evergreen and deciduous forest, dominated by large trees of Nothofagus (southern beech) and araucarian and podocarp conifers, with other angiosperms as mid-canopy trees and understorey shrubs. In comparison the Middle Eocene flora shows a 47 percent decrease in diversity with only 19 leaf morphotypes. The flora is dominated by Nothofagus, most similar to modern cool-temperate types, and has much rarer subtropical and warm-temperate types, such as Proteaceae. The decline in diversity indicates a substantial cooling of climate over this interval.

Paleoclimate data were derived using CLAMP (Climate Leaf Analysis Multivariate Program) (Wolfe and Spicer, 1999) and several leaf margin analysis techniques based on physiognomic properties of the leaves. CLAMP results are given below. A MAT of $13.5 \pm 0.7^{\circ} \mathrm{C}$ was determined for the 
Late Paleocene. A strongly seasonal climate was implied, with a warm month mean of $25.7 \pm 2.7^{\circ} \mathrm{C}$ and a cold month mean of $2.2 \pm 2.7^{\circ} \mathrm{C}$, with $2110 \mathrm{~mm}$ annual rainfall. By the Middle Eocene the climate had cooled considerably; the MAT was $10.8 \pm 1.1^{\circ} \mathrm{C}$ with a warm month mean of $24 \pm$ $2.7^{\circ} \mathrm{C}$, and a cold month mean of $-1.17 \pm 2.7^{\circ} \mathrm{C}$, with 1534 $\mathrm{mm}$ annual rainfall. This suggests that the climate was still markedly seasonal but that winter temperatures were often below freezing.

The Late Paleocene floras thus represent warm Antarctic climates probably without ice, even in winter. However, Seymour Island floras suggest that by the Middle Eocene (47-44 Ma) climates had cooled considerably and ice may have been present on the Antarctic continent, at least during winter months. Several Eocene macrofloras dominated by Nothofagus from King George Island, South Shetland Islands, suggest mean annual temperatures of about $10-11^{\circ} \mathrm{C}$ (seasonality unknown) (e.g., Birkenmajer and Zastawniak, 1989; Hunt and Poole, 2003), and the highest latitude Eocene floras, from Minna Bluff in the McMurdo Sound region, are suggestive of cool temperate climates (Francis, 2000). Other geological evidence also points to significant cooling by the latter part of the Eocene; fluctuating volumes of ice on Antarctica from about 42 Ma have been implied by Tripati et al. (2005) from isotope measurements of marine sediments and, from the Antarctic region, Birkenmajer et al. (2005) proposed a glacial period from 45-41 Ma, based on valley-type tillites of Eocene-Oligocene age from King
George Island. Ivany et al. (2006) have also reported the glacial deposits of possible latest Eocene or earliest Oligocene age from Seymour Island.

\section{PLANTS IN THE FREEZER}

Despite the onset of glaciation and the growth of ice sheets on Antarctica during the latest Eocene or earliest Oligocene, vegetation was not instantly wiped out but clung on tenaciously in hostile environments. Even though many warmthloving plant taxa disappeared during the mid-Eocene, floras dominated by Nothofagus remained for many millions of years. Single leaves of Nothofagus of Oligocene and Miocene age have been found in CRP-3 and CIROS-1 drill cores, respectively (Hill, 1989; Cantrill, 2001), but one of the most remarkable Antarctic floras is preserved within glacial diamictites of the Meyer Desert Formation, Sirius Group, at Oliver Bluffs $\left(85^{\circ} \mathrm{S}\right)$ in the Transantarctic Mountains.

In a meter-thick layer of sandstone, siltstone, and mudstone sandwiched between tillites, small twigs of fossil Nothofagus wood are preserved entwined around cobbles (Figure 6). The twigs are the branches and rootlets of small dwarf shrubs preserved within their positions of growth. Fossil leaf mats of Nothofagus leaves (Nothofagus beardmorensis) (Hill et al., 1996) are also preserved in the same horizon. Several other fossil plants have also been recovered, including moss cushions, liverworts, and fruits, stems, and seeds of several
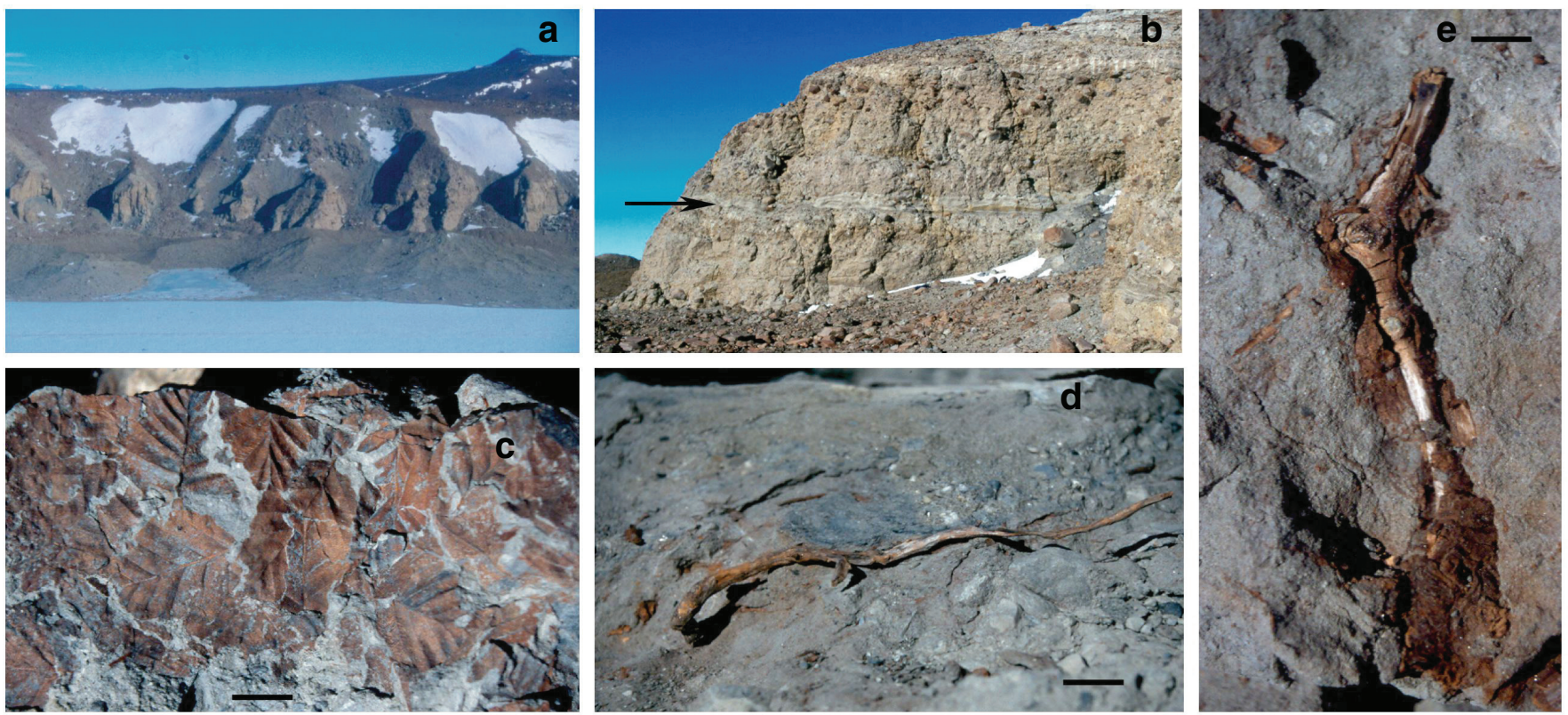

FIGURE 6 Sirius Group sediments and fossil plants, Oliver Bluffs, Transantarctic Mountains. (a) General view of Oliver Bluffs. (b) View of bluff composed of glacial diamictites. Arrow points to meter-thick horizon of glacial sandstone, equivalent to plant-bearing horizon. (c) Nothofagus leaves from upper part of plant-bearing horizon. (d) Small branch of fossil wood in growth position within paleosol horizon. (e) Small branch in situ in paleosol horizon, with delicate bark still attached. Scale bars represent $1 \mathrm{~cm}$. 
vascular plants, as well as remains of beetles, a gastropod, bivalves, a fish, and a fly (Ashworth and Cantrill, 2004).

All the evidence for paleoclimate from these remarkable fossils (Ashworth and Cantrill, 2004), from growth rings in the twigs (Francis and Hill, 1996), and from paleosols (Retallack et al., 2001) points toward a tundra environment with a mean annual temperature of about $-12^{\circ} \mathrm{C}$, with short summers up to $+5^{\circ} \mathrm{C}$ but with long cold winters below freezing. Dated as Pliocene in age but disputed (see Ashworth and Cantrill, 2004), this periglacial or interglacial environment existed at a time when glaciers retreated briefly from the Oliver Buffs region, allowing dwarf shrubs to colonize the exposed tundra surface only about $500 \mathrm{~km}$ from the South Pole.

As Antarctica's climate cooled further into the Pleistocene deep-freeze, vascular plants were lost from the continent. However, its rich fossil plant record retains its legacy of past warmth.

\section{ACKNOWLEDGMENTS}

New information presented here was obtained during postgraduate research projects of Howe (Alexander Island) and Stephens (Seymour Island), funded by Natural Environment Research Council and the British Antarctic Survey (BAS). Stephens wishes to thank Martin Dawson (Leeds) and Andreas Hillenbach and Hendrik Ballhausen (Institut Laue Langevin, Grenoble) for help with neutron tomography. New data on fossil plants from Seymour Island were collected as part of a NERC-Antarctic Funding Initiative project AFI1/01 to Francis, Cantrill, and Tosolini. BAS is thanked for field support in all these projects. Work in the Transantarctic Mountains was funded by NSF/OPP grants 9615252 and 0230696 to Ashworth. The Trans-Antarctic Association and Geological Society of London are thanked for additional support. This work has been aided by discussions with Hunt, Falcon-Lang, Hayes, Poole, Eklund (Leeds/BAS), and Roof.

\section{REFERENCES}

Ashworth, A. C., and D. J. Cantrill. 2004. Neogene vegetation of the Meyer Desert Formation (Sirius Group), Transantarctic Mountains, Antarctica. Palaeogeography, Palaeoclimatology, Palaeoecology 213:65-82.

Askin, R. A. 1992. Late Cretaceous-early Tertiary Antarctic outcrop evidence for past vegetation and climate. In The Antarctic Paleoenvironment: A Perspective on Global Change, eds. J. P. Kennett and D. A. Warnke, Antarctic Research Series 56:61-75. Washington, D.C.: American Geophysical Union.

Birkenmajer, K., and E. Zastawniak. 1989. Late Cretaceous-early Tertiary floras of King George Island, West Antarctica: Their stratigraphic distribution and palaeoclimatic significance, origins and evolution of the Antarctic biota. Geological Society of London Special Publication 147:227-240.

Birkenmajer, K., A. Gazdzicki, K. P. Krajewski, A. Przybycin, A. Solecki, A. Tatur, and H. I. Yoon. 2005. First Cenozoic glaciers in West Antarctica. Polish Polar Research 26:3-12.
Cantrill, D. J. 2001. Early Oligocene Nothofagus from CRP-3, Antarctica: Implications for the vegetation history. Terra Antarctica 8:401-406.

Cantrill, D. J., and J. Howe. 2001. Palaeoecology and taxonomy of Pentoxylales from the Albian of Antarctica. Cretaceous Research 22:779-793.

Cantrill, D. J., and I. Poole. 2002. Cretaceous to Tertiary patterns of diversity changes in the Antarctic Peninsula. In Palaeobiogeography and Biodiversity Change: A Comparison of the Ordovician and MesozoicCenozoic Radiations, eds. A. W. Owen and J. A. Crame, Geological Society of London Special Publication 194:141-152.

Cantrill, D. J., and I. Poole. 2005. Taxonomic turnover and abundance in Cretaceous to Tertiary wood floras of Antarctica: Implications for changes in forest ecology. Palaeogeography, Palaeoclimatology, Palaeoecology 215:205-219.

Clark, L. J., and H. C. Jenkyns. 1999. New oxygen isotope evidence for long-term Cretaceous climatic change in the Southern Hemisphere. Geology 27:699-702.

Dingle, R., and M. Lavelle. 1998. Late Cretaceous-Cenozoic climatic variations of the northern Antarctic Peninsula: New geochemical evidence and review. Palaeogeography, Palaeoclimatology, Palaeoecology 141:215-232.

Dutton, A., K. Lohmann, and W. J. Zinsmeister. 2002. Stable isotope and minor element proxies for Eocene climate of Seymour Island, Antarctica. Paleoceanography 17(5), doi:10.1029/2000PA000593.

Eklund, H. 2003. First Cretaceous flowers from Antarctica. Review of Palaeobotany and Palynology 127:187-217.

Eklund, H., D. J. Cantrill, and J. E. Francis. 2004. Late Cretaceous plant mesofossils from Table Nunatak, Antarctica. Cretaceous Research 25:211-228.

Elliot, D. H., and T. A. Trautman. 1982. Lower Tertiary strata on Seymour Island, Antarctic Peninsula. In Antarctic Geoscience, ed. C. Craddock, pp. 287-297. Madison: University of Wisconsin Press.

Falcon-Lang, H. J., D. J. Cantrill, and G. J. Nichols. 2001. Biodiversity and terrestrial ecology of a mid-Cretaceous, high-latitude floodplain, Alexander Island, Antarctica. Journal of the Geological Society of London 158:709-724.

Francis, J. E. 2000. Fossil wood from Eocene high latitude forests, McMurdo Sound, Antarctic. In Paleobiology and Palaeoenvironments of Eocene Rocks, McMurdo Sound, East Antarctica, eds. J. D. Stilwell and R. M. Feldmann, Antarctic Research Series 76:253-260, Washington, D.C.: American Geophysical Union.

Francis, J. E., and R. S. Hill. 1996. Fossil plants from the Pliocene Sirius group, Transantarctic Mountains: Evidence for climate from growth rings and fossil leaves. Palaios 11:389-396.

Francis, J. E., and I. Poole. 2002. Cretaceous and early Tertiary climates of Antarctica: Evidence from fossil wood. Palaeogeography, Palaeoclimatology, Palaeoecology 182:47-64.

Francis, J. E., S. Marenssi, R. Levy, M. Hambrey, V. T. Thorn, B. Mohr, H. Brinkhuis, J. Warnaar, J. Zachos, S. Bohaty, and R. DeConto. forthcoming. From Greenhouse to Icehouse-The Eocene/Oligocene in Antarctica,In Antarctic Climate Evolution, chap. 6, eds. F. Florindo and M. J. Siegert. Amsterdam: Elsevier.

Hayes, P. A., J. E. Francis, and D. J. Cantrill. 2006. Palaeoclimate of Late Cretaceous Angiosperm leaf floras, James Ross Island, Antarctic. In Cretaceous-Tertiary High Latitude Palaeoenvironments, James Ross Basin., eds. J. E. Francis, D. Pirrie, and J. A. Crame, Geological Society London Special Publication 258:49-62.

Hill, R. S. 1989. Palaeontology—fossil leaf. In Antarctic Cenozoic History from the CIROS-1 Drillhole, McMurdo Sound, ed. P. J. Barrett. New Zealand DSIR Bulletin 245:143-144.

Hill, R. S., D. M. Harwood, and P. N. Webb. 1996. Nothofagus beardmorensis (Nothofagaceae), a new species based on leaves from the Pliocene Sirius Group, Transantarctic Mountains, Antarctica. Review of Palaeobotany and Palynology 94:11-24.

Howe, J. 2003. Mid Cretaceous fossil forests of Alexander Island, Antarctic, Ph.D. thesis. University of Leeds, Leeds, U.K. 
Howe, J., and J. E. Francis. 2005. Metamorphosed palaeosols from the midCretaceous fossil forests of Alexander Island, Antarctica. Journal of the Geological Society of London 162:951-957.

Huber, B. T., R. D. Norris, and K. G. MacLeod. 2002. Deep-sea paleotemperature record of extreme warmth during the Cretaceous. Geology 30:123-126.

Hunt, R. J., and I. Poole. 2003. Paleogene West Antarctic climate and vegetation history in light of new data from King George Island. In Causes and Consequences of Globally Warm Climates in the early Paleogene, eds. S. L. Wing, P. D. Gingerich, B. Schmitz, and E. Thomas. Geological Society of America Special paper 369:395-412, Boulder, Colorado: Geological Society of America.

Ivany, L. C., S. Van Simaeys, E. W. Domack, and S. D. Samson. 2006. Evidence for an earliest Oligocene ice sheet on the Antarctic Peninsula. Geology 34:377-380.

Keating, J. M., M. Spencer-Jones, and S. Newham. 1992. The stratigraphical palynology of the Kotick Point and Whisky Bay formations, Gustav Group (Cretaceous), James Ross Island. Antarctic Science 4:279-292.

Lawver, L. A., L. M. Gahagan, and M. E. Coffin. 1992. The development of paleoseaways around Antarctica. In The Antarctic Paleoenvironment: A Perspective on Global Change, eds. J. P. Kennett and D. A. Warnke, Antarctic Research Series 56:7-30, Washington, D.C.: American Geophysical Union.

Marenssi, S. A. 2006. Eustatically controlled sedimentation recorded by Eocene strata of the James Ross Basin, Antarctic. In Cretaceous-Tertiary High-Latitude Palaeoenvironments, James Ross Basin, Antarctica, eds. J. E. Francis, D. Pirrie, and J. A. Crame, pp. 125-133. Geological Society of London Special Publication 258.

Marenssi, S. A., S. Santillana, and C. A. Rinaldi. 1998. Stratigraphy of the La Meseta Formation (Eocene), Marambio (Seymour) Island, Antarctic. In Paleógeno de América del Sur y de la Península Antártica. ed. S. Casadío, Asociación Paleontológica Argentina Publicación Especial 5:137-146. Buenos Aires: Asociación Paleontológica Argentina.

Nichols, G. J., and D. J. Cantrill. 2002. Tectonic and climatic controls on a Mesozoic fore-arc basin succession, Alexander Island, Antarctic. Geology Magazine 139:313-330.

Pirrie, D., J. D. Marshall, and J. A. Crame. 1998. Marine high-Mg calcite cements in Teredolites-bored fossil wood; evidence for cool paleoclimates in the Eocene La Meseta Formation, Seymour Island, Antarctic. Palaios 13:276-286.
Poole, I., D. Cantrill, and T. Utescher. 2005. A multi-proxy approach to determine Antarctic terrestrial palaeoclimate during the Late Cretaceous and early Tertiary. Palaeogeography, Palaeoclimatology, Palaeoecology 222:95-121.

Poulsen, C. J., A. S. Gendaszek, and R. L. Jacob. 2003. Did the rifting of the Atlantic Ocean cause the Cretaceous thermal maximum? Geology $31: 115-118$

Retallack, G. J., E. S. Krull, and G. Bockheim. 2001. New grounds for reassessing the palaeoclimate of the Sirius Group, Antarctica. Journal of the Geological Society of London 158:925-935.

Sadler, P. M. 1988. Geometry and stratification of uppermost Cretaceous and Paleogene units on Seymour Island, northern Antarctic Peninsula. In Geology and Paleontology of Seymour Island, Antarctic Peninsula, eds. R. M. Feldmann and M. O. Woodburne, Geological Society of America Memoir 169:303-320. Boulder, Colorado: Geological Society of America.

Stephens, R. 2008. Palaeoenvironmental and climatic significance of an Araucaria-dominated Eocene flora from Seymour Island, Antarctic. Ph.D. thesis. University of Leeds, Leeds, U.K.

Taylor, E. L., and T. N. Taylor. 1990. Structurally preserved Permian and Triassic floras from Antarctic. In Antarctic Paleobiology and Its Role in the Reconstruction of Gondwana, eds. T. N. Taylor and E. L. Taylor, pp. 149-163. New York: Springer-Verlag.

Tripati, A., J. Backman, H. Elderfield, and P. Ferretti. 2005. Eocene bipolar glaciation associated with global carbon cycle changes. Nature 436:341-346.

Valdes, P. J., B. W. Sellwood, and G. D. Price. 1996. Evaluating concepts of Cretaceous equability. Palaeoclimates, Data and Modelling 2:139-158.

Wolfe, J. A., and R. A. Spicer. 1999. Fossil leaf character states: Multivariate analysis. In Fossil Plants and Spores: Modern Techniques, eds. T. P. Jones and N. P. Rowe, pp. 233-239. London: Geological Society of London. 
This page intentionally left blank 